Please cite this paper as

Jurček A, Downes C, Keogh B, Urek M, Sheaf G, Hafford-Letchfield T, Buitenkamp C, van der Vaart N, Higgins A (2020) Educating health and social care practitioners on the experiences and needs of older LGBT+ adults: findings from a systematic review, Journal of Nursing Management, https://doi.org/10.1111/jonm.13145.

Please note that some minor changes may have been made to the paper in the final publication.

\title{
Educating health and social care practitioners on the experiences and needs of older LGBT+ adults: findings from a systematic review
}

\begin{abstract}
(200 words)
$\operatorname{Aim}(\mathbf{s})$ : To report review findings into interventions used to educate the health and social care workforce on the experiences and needs of LGBT+ older adults.

Background: Research demonstrates that inequalities in outcomes on health and social wellbeing for LGBT+ older adults are perpetuated by the cumulative disadvantages from discrimination and social exclusion throughout the life course and a lack of culturally competent workforce.
\end{abstract}

Evaluation: A systematic search of peer-reviewed papers published before February 2020 was conducted in electronic databases. The search resulted in a screening of 2509 papers with 9 matching the inclusion criteria which were rated using the MERSQI quality measure.

Key issue(s): Studies demonstrated some positive outcomes of interventions, especially an increase in knowledge, but less so in skills and attitudes.

Conclusion(s): More robust designs such as RCTs, the use of standardized measures and a focus more on the longitudinal impact of educational interventions could improve the quality of study designs. Diversification of intervention content and patient and public involvement in the design, delivery and evaluation of educational interventions could improve efforts and have a more sustained impact on LGBT+ ageing inequalities.

Implications for Nursing Management: Nurse managers have important roles in supporting staff education and ensuring LGBT+ inclusive practice.

Key words: LGBT+ older adults, Health practitioner, Social care, education interventions, systematic review 


\section{Introduction}

Globally, ageing populations are on the rise and the number of people aged 60 years or over is estimated to increase more than 120\% between 2019 and 2050 (United Nations World Population Aging, 2019). The need for health and social services is increasing, and both informal and formal support systems for ageing populations are coming under stress (United Nations Population Fund and HelpAge, 2012). At the same time, lesbian, gay, bisexual, transgender and gender diverse (LGBT+) people are becoming more visible, and sexual and gender minorities constitute one part of increasing diversity among older populations.

The specific needs of older sexual and gender minorities are getting more attention as it has been well established that older LGBT+ adults face specific health and social care issues (Cottrell, 2020). Similar to all older people, LGBT+ people may experience isolation (Fredriksen-Goldsen et al., 2013; Wilson et al., 2018), economic challenges (Emlet, 2016), and employment and housing discrimination (Fredriksen-Goldsen, 2017). However, they can be doubly disadvantaged due to cumulative discrimination and social exclusion throughout the life course, which has been linked to higher risk of poor mental health and substance misuse (Yarns et al. 2016). The intersectionality of discrimination from multiple minority identities has also been linked to a higher risk of abuse (Bloemen et al., 2019). Grossman et al. (2014) report that over a fifth of 113 older LGB participants experienced physical, emotional, verbal, sexual and financial abuse and neglect by caregivers. Due to the history of discrimination and 'othering' many older LGBT+ adults fear sexuality and/or gender identity-based discrimination in aged care settings should they disclose their sexual orientation or gender identity to health and social care services (Putney et al. 2018; Burton et al., 2019).

In addition to these challenges, older LGBT+ adults are four times more likely not to have children, twice as likely to live alone, and more likely to be estranged from their biological families (Stonewall, 2011; Zelle and Arms, 2015). Consequently, they are much more likely to rely on a more extensive social support network that may involve friends, partners and members of the LGBT+ community (Knauer, 2016). 
Gaps in knowledge and cultural competency of health and social care practitioners working with LGBT+ older adults needs attention but is yet to be prioritised (Bell et al., 2010; Greene et al. 2018; Nowaskie and Sowinski, 2019).

The call to action to address these gaps through education, culturally sensitive and inclusive curriculum and training approaches for health and social care professionals has been highlighted by scholars and activists (Cannon et al., 2017; De Guzman, 2018; LLayton and Caldas, 2020). This is essential to enable inclusive, accessible care for older LGBT+ adults (Putney et al., 2018; Smith et al., 2019). Hence this paper reports the findings from a systematic review into interventions used to educate the health and social care workforce on the experiences and needs of older LGBT+ adults, in order to guide and improve educational practice going forward.

\section{Aims of the review}

A systematic review following PRISMA guidelines was used to examine educational interventions. Its specific aims were to: i) describe interventions used to educate the health and social care workforce on the experiences and needs of older LGBT+ adults (defined as aged 55 and older); ii) describe the impact of these interventions on knowledge, attitudes and competence; and iii) discuss the evaluation designs of interventions, including quality.

\section{Methods}

A systematic search of the following electronic databases was undertaken by the librarian (GS): MEDLINE, CINAHL, PsycINFO, EMBASE, ERIC, Social Sciences Full Text (H.W. Wilson), and Web of Science. These included the main databases used in any health sciences-related systematic review, in addition to the most important databases for educational and social sciences research.

Previous reviews and the authors' knowledge were used to determine keywords, for example terms denoting health professionals and ones signifying education-related topics. In all cases, these terms were searched for, in titles and abstracts, and, where appropriate, other fields such as the "contributed indexing" field in MEDLINE. These were combined with controlled vocabulary terms such as MeSH and CINAHL Headings as appropriate (see example MEDLINE search strategy, Table 1). 
Table 1: Example MEDLINE (Ebsco) search

1. $\mathrm{MH}$ ("Homosexuality+" OR "Transsexualism" OR "Bisexuality") OR AB(asexual* OR bisexual* OR dyke* OR gay* OR "gender fluid*" OR "gender identit*" OR homophobi* OR homosexual* OR lesbian* OR LGB OR LGBT OR LGBTI OR LGBTQ OR LGBTQI OR LGBTQQI OR "non-binary" OR queer* OR "same sex" OR "sexual minorit*" OR "sexual orientation" OR transgender OR transsexual*) OR TI(asexual* OR bisexual* OR dyke* OR gay* OR "gender fluid*" OR "gender identit*" OR homophobi* OR homosexual* OR lesbian* OR LGB OR LGBT OR LGBTI OR LGBTQ OR LGBTQI OR LGBTQQI OR "non-binary" OR queer* OR "same sex" OR "sexual minorit*" OR "sexual orientation" OR transgender OR transsexual*) OR Cl(asexual* OR bisexual* OR dyke* OR gay* OR "gender fluid*" OR "gender identit*" OR homophobi* OR homosexual* OR lesbian* OR LGB OR LGBT OR LGBTI OR LGBTQ OR LGBTQI OR LGBTQQI OR "non-binary" OR queer* OR "same sex" OR "sexual minorit*" OR "sexual orientation" OR transgender OR transsexual*)

2. $\mathrm{MH}$ ("Aged+" OR "Middle Aged" OR "geriatrics") OR AB(ageis* OR elder* OR geriatric* OR gerontolog* OR "later life" OR "old age" OR older OR pensioner* OR senior OR seniors) OR TI(ageis* OR elder* OR geriatric* OR gerontolog* OR "later life" OR "old age" OR older OR pensioner* OR senior OR seniors) OR Cl(ageis* OR elder* OR geriatric* OR gerontolog* OR "later life" OR "old age" OR older OR pensioner* OR senior OR seniors)

3. MH“health personnel+" OR AB((health* OR hospital OR medical OR nurs* OR "operatingroom" OR paramedical OR pharmac* OR psychiatric OR social OR welfare) N2 (aide* OR assistant* OR consultant* OR officer* OR personnel OR practitioner* OR professional* OR provider* OR specialist* OR staff OR worker*)) OR (anesthetist* OR anaesthetist* OR audiologist* OR clinician* OR counselor* OR counsellor* OR dentist* OR dietitian* OR doctor* OR "general practitioner*" OR gp OR gps OR geriatrician* OR gerontologist* OR gynecologist* OR gynaecologist* OR hospitalist* OR nurse* OR nutritionist* OR obstetrician* OR pharmacist* OR physician* OR physiotherapist* OR psychiatrist* OR psychologist* OR psychotherapist* OR surgeon* OR therapist*) OR TI((health* OR hospital OR medical OR nurs* OR “operating-room" OR paramedical OR pharmac* OR psychiatric OR social OR welfare) N2 (aide* OR assistant* OR consultant* OR officer* OR personnel OR practitioner* OR professional* OR provider* OR specialist* OR staff OR worker*)) OR (anesthetist* OR anaesthetist* OR audiologist* OR clinician* OR counselor* OR counsellor* OR dentist* OR dietitian* OR doctor* OR "general practitioner*" OR gp OR gps OR geriatrician* OR gerontologist* OR gynecologist* OR gynaecologist* OR hospitalist* OR nurse* OR nutritionist* OR obstetrician* OR pharmacist* OR physician* OR physiotherapist* OR psychiatrist* OR psychologist* OR psychotherapist* OR surgeon* OR therapist*) OR Cl((health* OR hospital OR medical OR nurs* OR "operating-room" OR paramedical OR pharmac* OR psychiatric OR social OR welfare) N2 (aide* OR assistant* OR consultant* OR officer* OR personnel OR practitioner* OR professional* OR provider* OR specialist* OR staff OR worker*)) OR (anesthetist* OR anaesthetist* OR audiologist* OR clinician* OR counselor* OR counsellor* OR dentist* OR dietitian* OR doctor* OR "general practitioner*" OR gp OR gps OR geriatrician* OR gerontologist* OR gynecologist* OR gynaecologist* OR hospitalist* OR nurse* OR nutritionist* OR obstetrician* OR pharmacist* OR physician* OR physiotherapist* OR psychiatrist* OR psychologist* OR 


\begin{tabular}{|l|}
\hline psychotherapist* OR surgeon* OR therapist*) \\
\hline 4. \\
MH“education+" OR AB(assess* OR class* OR course* OR “cultural competenc*” OR \\
curricul* OR education* OR eLearning OR evaluat* OR knowledge OR learn* OR module* \\
OR pedagog* OR skill* OR syllabus* OR teach* OR train*) OR TI(assess* OR class* OR \\
course* OR “cultural competenc*” OR curricul* OR education* OR eLearning OR evaluat* \\
OR knowledge OR learn* OR module* OR pedagog* OR skill* OR syllabus* OR teach* OR \\
train*) OR CI(assess* OR class* OR course* OR "cultural competenc* OR curricul* OR \\
education* OR eLearning OR evaluat* OR knowledge OR learn* OR module* OR pedagog* \\
OR skill* OR syllabus* OR teach* OR train*)
\end{tabular}

Search consisted of 1 AND 2 AND 3 AND 4. Limited to English results.

The search was limited to peer-reviewed papers published before February 2020 and in the English language. These search boundaries resulted in 2991 papers. After duplicates were removed, the resulting 2509 papers were screened according to the following inclusion and exclusion criteria (see Table 2).

\section{Table 2: Inclusion/exclusion criteria}

\section{Inclusion criteria were:}

i. empirical studies using any research design;

ii. evaluated educational interventions focusing on the experiences and needs of older LGBT+ adults;

iii. target population included health practitioners (nurses, doctors, psychologists, physiotherapists, occupational and speech and language therapists) social care practitioners (social workers or care staff) or other staff working in aged care services irrespective of educational level;

iv. conducted in any setting (hospital, community);

v. used any educational format (online, face-to-face); and

vi. reported on any educational or practice outcomes.

\section{Exclusion criteria were}

i. studies focused exclusively on descriptions of an educational intervention without evaluation findings;

ii. studies focused on evaluating educational interventions on sexuality but did not identify issues in relation to older LGBT+ adults.

Covidence screening software (www.covidence.org) was used to manage the screening process. Two reviewers independently assessed each title and abstract against the inclusion/exclusion criteria to identify potentially relevant papers $(A H, C D)$ and any 
discrepancies were resolved by a third reviewer (BK). For stage two screening, the full texts of 25 papers were obtained and assessed independently by the same two reviewers and any discrepancies were resolved by discussion. This stage resulted in the exclusion of a further 17 papers, primarily due to not being evaluation studies or the intervention not including issues relating to the older LGBT+ population. Following this, reference lists in these papers were reviewed, which resulted in the addition of one further paper. Figure 1 shows the PRISMA diagram.

\section{Figure1: PRISMA Flow Diagram of Selection Process}

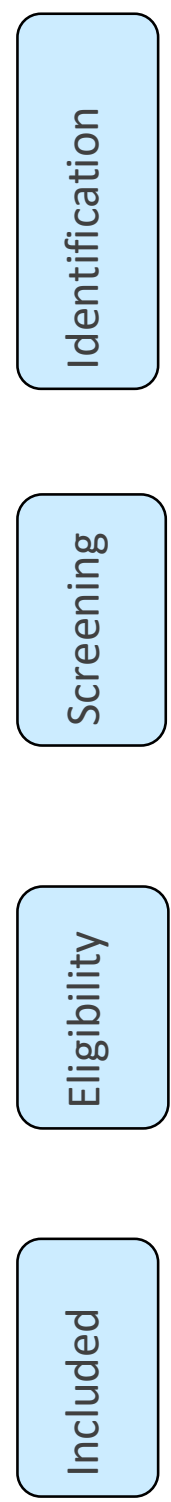

Titles and abstracts identified and screened through electronic database searches

$$
(n=2991)
$$

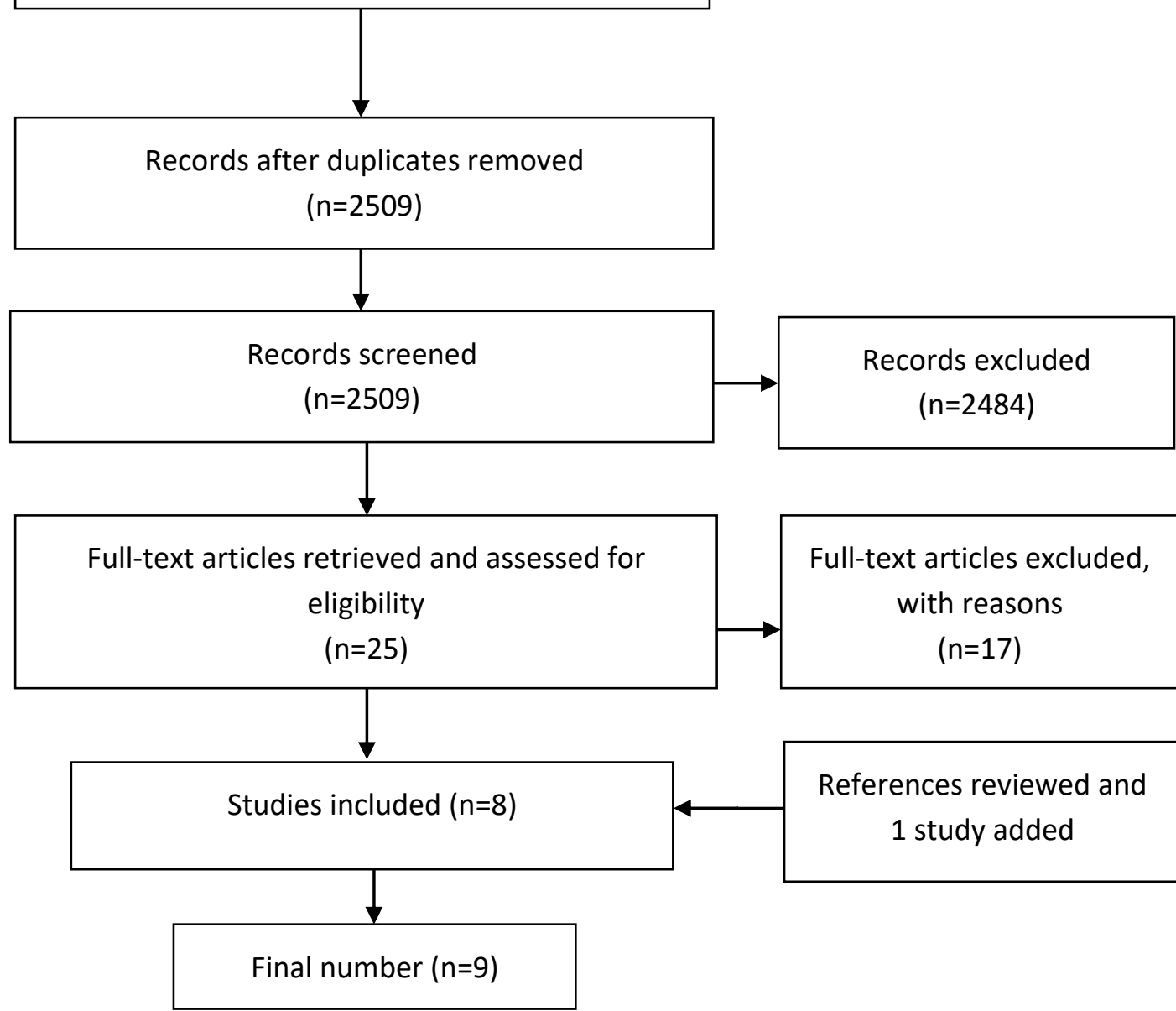




\section{Quality Appraisal}

A quality assessment using the medical education research study quality instrument (MERSQI) (Reed, et al. 2007) was completed. The MERSQI was considered appropriate as it had been used in previous reviews of educational interventions (Brennan and Mattick, 2012; Smith and Learman, 2017; Kothari et al., 2011) and was designed for observational or experimental study designs. The tool consists of six items (study design, sampling, type of data, validity of evaluation instrument, data analysis and outcomes) which are scored on a scale of 1 to 3 and summed to determine a total MERSQI score. The maximum score for each domain is 3 ( 3 is the highest quality), producing a maximum possible score of 18 . Two reviewers independently scored each paper (THL, MU) and came together to agree on the final score. Overall there was a high level of consistency in scoring between the reviewers. The range of scores for the included studies was 9 to 14.5 (scores for each study are reported in table 3). The main reasons for the low scoring were: the absence of randomised control studies; the non-use of objective measures or lack of reporting on the validity of measures used; and the absence of measures to capture practice focused outcomes, such as change in the behaviour of participants and outcomes from the perspective of LGBT+ older adults.

\section{Data extraction}

An extraction table was developed, piloted and applied across the studies to record information based on the aims of the review. In addition to extracting information on the nature and type of intervention, core data on evaluation methodology and findings were extracted (see Table 3). To ensure consistency data extraction was completed by at least two people $(A J, A H, C D)$.

\section{Table 3: Overview of included papers}




\begin{tabular}{|c|c|c|c|c|c|}
\hline $\begin{array}{l}\text { Author } \\
\text { (Date) } \\
\text { Countr } \\
\text { y of } \\
\text { origin } \\
\text { Quality } \\
\text { score }\end{array}$ & Aim of paper & Intervention (description) & Evaluation & $\begin{array}{c}\text { Sample and Location } \\
\text { (size and characteristics) }\end{array}$ & Findings \\
\hline $\begin{array}{l}\text { Gendro } \\
\text { n et al. } \\
\text { (2013) } \\
\text { USA } \\
\text { QS: } \\
14,5\end{array}$ & $\begin{array}{l}\text { Describe the } \\
\text { development of the } \\
\text { LGBT Cultural } \\
\text { Competency Project, } \\
\text { evaluate the efficacy of } \\
\text { the program and } \\
\text { examine the } \\
\text { curriculum revisions } \\
\text { based on the outcome } \\
\text { of the evaluation. }\end{array}$ & $\begin{array}{l}\text { Intervention: Face-to-face. } \\
\text { Content: Definitions, symbols, } \\
\text { facts, and assumptions related to } \\
\text { LGBT issues. Strategies for } \\
\text { recognizing barriers to inclusion } \\
\text { and developing the skills to provide } \\
\text { culturally competent care. } \\
\text { Teaching methods: Didactic } \\
\text { teaching, interactive exercises and } \\
\text { small group activities. Use of } \\
\text { documentary footage of the movie } \\
\text { Gen Silent (2010). } \\
\text { Delivery: Teams of two trainers } \\
\text { and a facilitator. } \\
\text { Duration: Two and four hour } \\
\text { sessions format. }\end{array}$ & $\begin{array}{l}\text { Design: Process evaluation involving } \\
\text { multisite pre- post-survey, observation } \\
\text { and interviews. } \\
\text { Data collection methods: } \\
\text { Survey measuring knowledge } \\
\text { (awareness) and comfort, as well as } \\
\text { concerns, recommendation and } \\
\text { whether they would recommend } \\
\text { training to others. Survey designed for } \\
\text { the study. Observation of training } \\
\text { session and semi-structured interviews } \\
\text { (used individually and in focus groups). } \\
\text { Interviews were conducted with six } \\
\text { participants and three stakeholders. } \\
\text { Data collection time point: Surveys } \\
\text { immediately before and after the } \\
\text { training. Interviews and observation } \\
\text { occurred during and after the training. }\end{array}$ & $\begin{array}{l}\text { Sample size and location: } \mathrm{N}=199 \\
\text { participants in community-based } \\
\text { healthcare facilities and state-wide } \\
\text { healthcare organizations (5 sites). } \\
\text { Attrition rate of } 18 \% \text { (attended } \\
\text { training but didn't complete pre- } \\
\text { post). } \\
\text { Sample Characteristics: } \\
\text { Discipline: Staff working with the } \\
\text { aging population (administrative and } \\
\text { direct-care-level staff). Exact } \\
\text { disciplines were not reported. } \\
\text { Gender: } 83 \% \text { women, } 17 \% \text { male. } \\
\text { Sexual orientation: Not reported. } \\
\text { Ethnicity: } 46 \% \text { Caucasian, } 48 \% \text {. } \\
\text { African American, 3\% Asian, } 1 \% \\
\text { Latino. } \\
\text { Age: } 17 \% 20-29,19 \% 30-39,25 \% 40- \\
49,25 \% 50-59,13 \% 60+. \\
\text { Education: } 37 \% \text { High School, } 8 \% \\
\text { Associate's degree, } 4 \% \text { Certification } \\
\text { diploma, } 23 \% \text { Baccalaureate, } 17 \% \\
\text { Master's degree, 3\% Doctoral, } 7 \% \\
\text { other. } \\
\text { Work Experience: Not reported. } \\
\text { Income: Not reported. }\end{array}$ & $\begin{array}{l}\text { Impact of intervention on } \\
\text { participants: } \\
\text { Increase in knowledge (awareness) } \\
\text { of aging LGBT's healthcare issues. } \\
\text { Increase in the level of comfort } \\
\text { caring for a member of the LGBT } \\
\text { community. The increase was not } \\
\text { demonstrated at every site. } \\
\text { Intervention Evaluation: High ratings } \\
\text { of the workshops. } 90-100 \% \text { of } \\
\text { participants per site recommended } \\
\text { the training for colleagues and co- } \\
\text { workers. Several participants } \\
\text { reported that the four-hour training } \\
\text { was too long for this topic. } \\
\text { Participants appeared most engaged } \\
\text { during interactive group activities } \\
\text { and least engaged by the didactic } \\
\text { portion of the training. The clips } \\
\text { elicited strong reactions and a high } \\
\text { level of engagement, with minor } \\
\text { negative stances. Stakeholders } \\
\text { indicated that there were numerous } \\
\text { benefits of training staff, and } \\
\text { decided to make the training } \\
\text { mandatory for all staff and } \\
\text { implement new LGBT relevant policy. }\end{array}$ \\
\hline Rogers & $\begin{array}{l}\text { Evaluate the impact of } \\
\text { training panels }\end{array}$ & $\begin{array}{l}\text { Intervention: Face-to-face. } \\
\text { Content: Issues faced by older }\end{array}$ & $\begin{array}{l}\text { Design: Multisite post survey } \\
\text { Data collection methods: } 3 \text { item }\end{array}$ & $\begin{array}{l}\text { Sample size and location: } \mathrm{N}=605 \\
\text { (+34 sites) students and }\end{array}$ & $\begin{array}{l}\text { Impact of intervention on } \\
\text { participants: } 82 \% \text { of participants }\end{array}$ \\
\hline
\end{tabular}




\begin{tabular}{|c|c|c|c|c|c|}
\hline $\begin{array}{l}\text { et al. } \\
\text { (2013) } \\
\text { USA- } \\
\text { Portlan } \\
\text { d, } \\
\text { Oregon } \\
\text { QS: } 10\end{array}$ & $\begin{array}{l}\text { provided by older LGBT } \\
\text { adults on participants. }\end{array}$ & $\begin{array}{l}\text { LGBT adults and how } \\
\text { discrimination impacts their lives. } \\
\text { Personal and social impacts on } \\
\text { older LGBT adults who must hide } \\
\text { their sexual orientation due to } \\
\text { personal, social or institutional } \\
\text { pressures. } \\
\text { Teaching methods: Video of } \\
\text { personal narratives by panel } \\
\text { members, exercise on keeping a } \\
\text { secret and discussion. } \\
\text { Delivery: Training given by a panel } \\
\text { of older LGBT adult volunteers of } \\
\text { the Gay Grey Program (GGP). } \\
\text { Duration: Not reported. }\end{array}$ & $\begin{array}{l}\text { survey using a } 5 \text { point Likert scale } \\
\text { designed specifically for the study with } \\
\text { open-ended questions to measure } \\
\text { awareness and satisfaction with the } \\
\text { intervention. } \\
\text { Data collection time point: } \\
\text { Immediately at the conclusion of the } \\
\text { training. }\end{array}$ & $\begin{array}{l}\text { professionals from education and } \\
\text { community agencies settings who } \\
\text { completed evaluation surveys from } \\
2005 \text { to } 2011.79,5 \% \text { of training was } \\
\text { in university settings and } 20,5 \% \text { in } \\
\text { community agency. } \\
\text { Sample Characteristics: } \\
\text { Discipline: Not reported for overall } \\
\text { sample. Undergraduate student } \\
\text { sample: } 45 \% \text { nursing, } 11 \% \text { social } \\
\text { work \& remainder from wide range } \\
\text { of other non-health related } \\
\text { disciplines } \\
\text { Gender: } 81,8 \% \text { women, } 16 \% \text { male, } \\
2,2 \% \text { other. } \\
\text { Sexual Orientation: } 81,8 \% \\
\text { heterosexual, } 14,3 \% \text { LGB, } 2,2 \% \\
\text { queer, } 1,7 \% \text { other. } \\
\text { Ethnicity: } 82,7 \% \text { Caucasian, } 6,6 \% \\
\text { Asian, 3,2\% Black/African American, } \\
2,5 \% \text { Hispanic, } 5 \% \text { Other. } \\
\text { Age: } 17-83 \text { range, average } 30 \text { years. } \\
\text { Education: Not reported. } \\
\text { Work Experience: Not reported. } \\
\text { Income: } 61,9 \% \text { 0-15,999\$, 10,6\% } \\
\text { 16,000-29,999\$, } 27,5 \% 30,000+\$ .\end{array}$ & $\begin{array}{l}\text { made comments related to how the } \\
\text { training helped raise their } \\
\text { awareness. Participants also felt } \\
\text { more accepting of the community in } \\
\text { general. } \\
\text { Intervention Evaluation: } 76 \% \text { of } \\
\text { participants rated the exercise } \\
\text { "keeping the secret" as very good to } \\
\text { excellent. } 94 \% \text { rated the elder panel } \\
\text { presentation and the overall training } \\
\text { as very good to excellent. } \\
\text { Participants thought the trainings } \\
\text { should be offered and even required } \\
\text { through college courses and agency } \\
\text { trainings. Participants felt that the } \\
\text { older adults created a safe and } \\
\text { comfortable environment. Honesty } \\
\text { and openness of trainers helped to } \\
\text { build empathy. }\end{array}$ \\
\hline $\begin{array}{l}\text { Hardac } \\
\text { ker et } \\
\text { al. } \\
(2014)^{2} \\
\text { USA - } \\
\text { Chicag } \\
\text { o and } \\
\text { surrou }\end{array}$ & $\begin{array}{l}\text { Describe the } \\
\text { development, } \\
\text { implementation and } \\
\text { evaluation of a module } \\
\text { curriculum entitled, } \\
\text { 'Health Education } \\
\text { about LGBT Elders } \\
\text { (HEALE) targeted at } \\
\text { nurses and health-care }\end{array}$ & $\begin{array}{l}\text { Intervention: Face-to-face. } \\
\text { Content: HEALE - cultural } \\
\text { competency curriculum: Six 1-hour } \\
\text { modules: (1) an introduction to the } \\
\text { LGBT elder community, (2) barriers } \\
\text { to health care and health } \\
\text { disparities, (3) sex and sexuality of } \\
\text { LGBT elders, (4) legal concerns for } \\
\text { the LGBT elder, (5) an introduction }\end{array}$ & $\begin{array}{l}\text { Design: Multisite pre- post-survey. } \\
\text { Data collection methods: Survey } \\
\text { included true/false knowledge } \\
\text { questions and open questions. } \\
\text { Data collection time point: Before and } \\
\text { immediately after each module. }\end{array}$ & $\begin{array}{l}\text { Sample size and location: } \\
\text { Nurses and health care staff from } \\
\text { academic centres, health centres, } \\
\text { home health centre and nursing } \\
\text { homes ( } 23 \text { sites). } \\
\text { Module } 1: \mathrm{N}=848 \\
\text { Module } 2: \mathrm{N}=671 \\
\text { Module } 3: \mathrm{N}=619 \\
\text { Module 4: } \mathrm{N}=584\end{array}$ & $\begin{array}{l}\text { Impact of intervention on } \\
\text { participants: Statistically significant } \\
\text { gains in knowledge in all modules. } \\
\text { Significant improvement of } \\
\text { knowledge was observed in both } \\
\text { educational and hospital setting and } \\
\text { in nursing home and home health- } \\
\text { care settings. The participants in the } \\
\text { latter had lower pre-test scores and }\end{array}$ \\
\hline
\end{tabular}




\begin{tabular}{|c|c|c|c|c|c|}
\hline $\begin{array}{l}\text { nding } \\
\text { areas } \\
\text { QS: } 13\end{array}$ & staff. & $\begin{array}{l}\text { to the transgender community, (6) } \\
\text { human immunodeficiency virus } \\
\text { (HIV) and aging. } \\
\text { Teaching methods: Primarily } \\
\text { didactic, with activity on } \\
\text { conducting a sexual history. } \\
\text { Opportunities for and comments at } \\
\text { the end of each module. } \\
\text { Delivery: Howard Brown Health } \\
\text { Center staff. } \\
\text { Duration: Six 1-hour modules } \\
\text { delivered over a } 6 \text { week period or } \\
\text { in multiple sessions per day. }\end{array}$ & & $\begin{array}{l}\text { Module 5: } \mathrm{N}=592 \\
\text { Module 6: } \mathrm{N}=537 \\
\text { Sample Characteristics: } \\
\text { See paper for characteristics of } \\
\text { participants from each module. } \\
\text { Summary from all modules: } \\
\text { Discipline: Nursing and other health } \\
\text { care staff (exact discipline not } \\
\text { reported). } \\
\text { Gender: Majority female (75-82\%), } \\
\text { male (17-22\%), transgender (1-3\%). } \\
\text { Sexual Orientation: Not reported. } \\
\text { Ethnicity: Majority either White (36- } \\
\text { 40\%), Black (approx. } 20-25 \%) \text { or } \\
\text { Asian (approx. 22-29\%). } \\
\text { Age: under 30 years (23-27\%), 30-39 } \\
\text { (18-20\%), } 40-49 \text { (16-22\%), 50-59 (24- } \\
\text { 28\%), } 60+(11-12 \%) . \\
\text { Education: } 35-38 \% \text { Registered } \\
\text { Nurses or had a Bachelor of Science } \\
\text { in Nursing, } 10 \% \text { Master of Science in } \\
\text { Nursing, } 13-18 \% \text { Certified nurse } \\
\text { assistants, 4-8\% Licensed practical } \\
\text { nurse \& }<5 \% \text { Doctor of Medicine or } \\
\text { medical student. } \\
\text { Work Experience: Not reported. } \\
\text { Income: Not reported. }\end{array}$ & $\begin{array}{l}\text { smaller knowledge gains in each of } \\
\text { the six modules. Evaluations suggest } \\
\text { enlightened attitude towards LGBT } \\
\text { patients. Those that attended the full } \\
\text { 6-week training showed increased } \\
\text { empathy. } \\
\text { Intervention Evaluation: The } \\
\text { curriculum was rated favourably in } \\
\text { terms of presentation style and } \\
\text { meeting objectives. Over } 95 \% \text { rated } \\
\text { the presenter as excellent or good } \\
\text { and approximately } 80 \% \text { gave the } \\
\text { highest rating for meeting session } \\
\text { objectives. Those who discontinued } \\
\text { the training were identified by their } \\
\text { peers as uncomfortable with the } \\
\text { LGBT community, they felt forced to } \\
\text { attend and believed they already } \\
\text { treated all the patients the same, } \\
\text { indicating a level of cultural } \\
\text { blindness instead of cultural } \\
\text { competency. Some groups refused to } \\
\text { attend, even if that meant risking } \\
\text { their jobs. }\end{array}$ \\
\hline $\begin{array}{l}\text { Porter } \\
\& \\
\text { Krinsky } \\
\text { (2014) } \\
\text { USA- } \\
\text { Massac }\end{array}$ & $\begin{array}{l}\text { Evaluate the impact of } \\
\text { cultural competency } \\
\text { training on the unique } \\
\text { challenges of sexual } \\
\text { and gender minorities } \\
\text { on elder-service } \\
\text { providers' attitudes, }\end{array}$ & $\begin{array}{l}\text { Intervention: Face-to-face. } \\
\text { Content: Addressing the myths and } \\
\text { realities of LGBT aging, prejudice } \\
\text { and barriers to providing quality } \\
\text { services for LGBT older adults and } \\
\text { developing strategies for improving } \\
\text { access and enhancing knowledge }\end{array}$ & $\begin{array}{l}\text { Design: Pre- post-survey. } \\
\text { Data collection methods: } 32 \text { item } \\
\text { survey. In addition to demographics, } \\
\text { survey included } 15 \text { five-point Likert } \\
\text { questions to measure comfort, } \\
\text { awareness and attitudes; } 7 \text { true false } \\
\text { questions to assess knowledge and }\end{array}$ & $\begin{array}{l}\text { Sample size and location: } \\
\mathrm{N}=76 \text { completed training and } \\
\text { evaluation. Service providers of older } \\
\text { adults (direct service, managers and } \\
\text { supervisors) working in } 4 \text { Area } \\
\text { Agencies on Aging (AAAs) in Eastern } \\
\text { Massachusetts. }\end{array}$ & $\begin{array}{l}\text { Impact of intervention on } \\
\text { participants: Statistically significant } \\
\text { positive changes in attitudes and } \\
\text { comfort. Question about being } \\
\text { comfortable providing services to an } \\
\text { openly transgender elder was the } \\
\text { only one that scored lower levels of }\end{array}$ \\
\hline
\end{tabular}




\begin{tabular}{|c|c|c|c|c|c|}
\hline $\begin{array}{l}\text { husetts } \\
\text { QS: } 13\end{array}$ & beliefs, and intentions. & $\begin{array}{l}\text { about public policies of importance } \\
\text { to older LGBT adults. } \\
\text { Teaching methods: Limited } \\
\text { information bar reference to a } \\
\text { workshop format. } \\
\text { Delivery: Facilitator - a member of } \\
\text { the LGBT Aging Project. } \\
\text { Duration: } 5 \text { hours. }\end{array}$ & $\begin{array}{l}\text { four questions to measure behavioural } \\
\text { intensions. } \\
\text { Data collection time point: Before and } \\
\text { immediately after the training. }\end{array}$ & $\begin{array}{l}\text { Sample Characteristics: } \\
\text { Discipline: } 65 \% \text { direct service, 35\% } \\
\text { manager/supervisor. Exact } \\
\text { disciplines not reported. } \\
\text { Gender: } 91 \% \text { women, } 8 \% \text { men, } 1 \% \\
\text { transgender. } \\
\text { Sexual Orientation: } 81,3 \% \\
\text { heterosexual, } 13,3 \% \text { gay/lesbian, } \\
\text { bisexual 5,3\%. } \\
\text { Ethnicity: } 92,1 \% \text { Caucasian, 1,3\% } \\
\text { Black/African American, 2,6\% } \\
\text { Asian/Asian American, 3,9\% Other. } \\
\text { Age: Not reported. } \\
\text { Education: Not reported. } \\
\text { Work Experience: Not reported. } \\
\text { Income: Not reported. }\end{array}$ & $\begin{array}{l}\text { comfort in post-test than in pre-test. } \\
\text { Statistically significant increases in } \\
\text { knowledge. Awareness of LGBT } \\
\text { resources were the only questions } \\
\text { where an increase in knowledge was } \\
\text { bigger among heterosexual } \\
\text { participants. Only } 1 / 4 \text { questions } \\
\text { regarding behaviour intentions, gave } \\
\text { statistically significant differences. } \\
\text { LGBT participants scored higher on } \\
\text { both pre- and post-test, compared to } \\
\text { heterosexual counterparts. } \\
\text { Intervention Evaluation: Not } \\
\text { gathered. }\end{array}$ \\
\hline $\begin{array}{l}\text { Hughes } \\
\text { et al. } \\
\text { (2016) } \\
\text { USA } \\
\text { QS: } 9.5\end{array}$ & $\begin{array}{l}\text { To describe the } \\
\text { development and } \\
\text { evaluation of an } \\
\text { interactive theatre } \\
\text { experience designed to } \\
\text { raise awareness among } \\
\text { health care providers, } \\
\text { students and the LGBT } \\
\text { community. }\end{array}$ & $\begin{array}{l}\text { Intervention: Face-to-face. } \\
\text { Content: Scripted and sketch } \\
\text { "Aggies's story", addressing } \\
\text { specific issues LGBT older people } \\
\text { face in everyday lives, } \\
\text { interpersonal and systemic bias in } \\
\text { health care systems and policies. } \\
\text { Teaching methods: } \\
\text { Facilitated theatre experience, the } \\
\text { theatre script was followed by } \\
\text { facilitated discussion including } \\
\text { audience questions, observations, } \\
\text { and small group work aimed at } \\
\text { establishing best practices, policies } \\
\text { and procedures. At the end the } \\
\text { whole group makes a list of take- } \\
\text { away points. } \\
\text { Delivery: Facilitator and actors } \\
\text { playing the roles. }\end{array}$ & $\begin{array}{l}\text { Design: Single group pre- post-survey } \\
\text { and guided discussion. } \\
\text { Data collection methods: Survey used } \\
\text { Likert scale questions and open-ended } \\
\text { questions. Different questions were } \\
\text { used pre and post-tests. The pre } \\
\text { survey had questions on experience of } \\
\text { working with LGBT older people and } \\
\text { knowing their particular needs. The } \\
\text { post survey addressed knowledge } \\
\text { gained and incentive to use it in } \\
\text { practice. Open-ended questions } \\
\text { focused on the theatre experience. } \\
\text { Feedback generated through guided } \\
\text { discussion following performance was } \\
\text { also collected. } \\
\text { Data collection time point: Before and } \\
\text { immediately after the intervention. }\end{array}$ & $\begin{array}{l}\text { Sample size and location: } \mathrm{N}=225 \\
\text { (convenience sample recruited at } 3 \\
\text { aging services conferences). 204/225 } \\
\text { completed surveys. 91\% response } \\
\text { rate. } \\
\text { Sample Characteristics: } \\
\text { Providers in the aging services } \\
\text { network, in long-term care and } \\
\text { public mental health providers and } \\
\text { administrators. } \\
\text { No further demographic data were } \\
\text { collected. }\end{array}$ & $\begin{array}{l}\text { Impact of intervention on } \\
\text { participants: } 75 \% \text { of participants } \\
\text { reported increased understanding of } \\
\text { the needs of older LGBT people. } 86 \% \\
\text { reported being better prepared to } \\
\text { provide services to older LGBT adults } \\
\text { and showed intention to use } \\
\text { knowledge gained in their work } \\
\text { setting. Guided discussions resulted } \\
\text { in identifying challenges to improving } \\
\text { care in work settings, such as } \\
\text { prejudice of the staff, other residents } \\
\text { or their families, lack of education } \\
\text { and training of staff. } \\
\text { Intervention Evaluation: } \\
\text { Respondents showed enthusiasm } \\
\text { about the play and guided } \\
\text { discussions, noting that the story } \\
\text { illuminated the complex nature of }\end{array}$ \\
\hline
\end{tabular}




\begin{tabular}{|c|c|c|c|c|c|}
\hline & & Duration: $1.5-2$ hours. & & & $\begin{array}{l}\text { caregiving relationships and subtle } \\
\text { ways that personal or cultural biases } \\
\text { affect these interactions. Other } \\
\text { feedback focused on how everyone } \\
\text { is treated the same in their facilities, } \\
\text { that they are non-biased and don't } \\
\text { see the need to keep talking about } \\
\text { difference. }\end{array}$ \\
\hline $\begin{array}{l}\text { Pelts } \\
\text { and } \\
\text { Galamb } \\
\text { os } \\
(2017) \\
\text { USA } \\
\text { QS: } 11\end{array}$ & $\begin{array}{l}\text { To explore how } \\
\text { Intergroup contact } \\
\text { through the use of } \\
\text { storytelling as a } \\
\text { training mechanism } \\
\text { influences Long Term } \\
\text { Care staff members' } \\
\text { attitudes related to } \\
\text { serving LG older adults. }\end{array}$ & $\begin{array}{l}\text { Intervention: Face-to-face. } \\
\text { Content: Intervention informed by } \\
\text { Intergroup contact (IGC) theory } \\
\text { and addressed the impact of } \\
\text { marginalization over the lifetime } \\
\text { from the perspective of the } \\
\text { storyteller and how identifying as a } \\
\text { sexual minority impacts work life, } \\
\text { personal relationships with family } \\
\text { and interactions with service } \\
\text { providers. } \\
\text { Teaching methods: Use of video } \\
\text { documentary (20 minutes), } \\
\text { including storyteller's personal } \\
\text { experience and group discussion. } \\
\text { Delivery: Primary researcher as } \\
\text { facilitator and a research assistant. } \\
\text { Duration: Not reported. }\end{array}$ & $\begin{array}{l}\text { Design: Single group, pre- post-survey } \\
\text { with an embedded qualitative } \\
\text { element. } \\
\text { Data collection methods: Survey: } \\
\text { attitudes were measured using the } \\
\text { morality measure from the } \\
\text { Component of Attitudes toward } \\
\text { Homosexuality Scale (LaMar \& Kite, } \\
\text { 1998). } 20 \text { items measuring attitude } \\
\text { toward leasbian women and gay men } \\
\text { using a 5-point Likert scale. Qualitative } \\
\text { data consisted of open-ended } \\
\text { questions in post-test survey, audio- } \\
\text { recorded group discussions, field notes } \\
\text { and memos. } \\
\text { Data collection time point: Before and } \\
\text { immediately after the intervention. }\end{array}$ & $\begin{array}{l}\text { Sample size and location: } N=60 \text { staff } \\
\text { members working in } 3 \text { long-term } \\
\text { care settings who completed } \\
\text { training. } N=42 \text { matched pairs for } \\
\text { data analysis. } \\
\text { Sample Characteristics: } \\
\text { Discipline: } 42 \% \text { nursing, } 19 \% \\
\text { activities or other support (19\%), } \\
12 \% \text { social workers/social services, } \\
10 \% \text { registered nurses (10\%), 9\% } \\
\text { licensed practical nurses \& } 8 \% \text { other. } \\
\text { Gender: } 81 \% \text { female, } 19 \% \text { male. } \\
\text { Sexual orientation: LG participants } \\
\text { were removed from sample. } \\
\text { Ethnicity: } 83 \% \text { Caucasian, } 9 \% \\
\text { Black/African American, } 6 \% \\
\text { Hispanic/Latino, } 2 \% \text { Other. } \\
\text { Age: Mean age } 38 . \\
\text { Education: } 35 \% \text { reported certificate, } \\
27 \% \text { reported high schoold } \\
\text { diploma/GED/college, } 14 \% \\
\text { associate's degree, } 12 \% \text { bachelor's } \\
\text { degree, } 12 \% \text { graduate degree. } \\
\text { Work Experience: On average } 11 y \text {. } \\
\text { Income: Not reported. }\end{array}$ & $\begin{array}{l}\text { Impact of intervention on } \\
\text { participants: Effect size was } \\
\text { measured (using Cohen's } d \text { ) and the } \\
\text { results suggest that the intervention } \\
\text { had moderate effects on } \\
\text { participants' attitudes towards } \\
\text { lesbian women and gay men. } \\
\text { Qualitative analysis revealed } 4 \\
\text { themes: (1) Making meaning of } \\
\text { stories illustrated how staff increased } \\
\text { their awareness by connecting } \\
\text { information from the storytelling to } \\
\text { societal laws and agency policy. The } \\
\text { theme (2) seeking understanding } \\
\text { reflected on participants expressed } \\
\text { desires to understand the context of } \\
\text { stories and further understand } \\
\text { personal experiences. (3) Application } \\
\text { of } L T C \text { and honouring individuals } \\
\text { consisted of participants descriptions } \\
\text { of ways to apply what they learned } \\
\text { in care delivery. (4) Debating } \\
\text { included passionate conversations } \\
\text { about controversial matters such as } \\
\text { concerns about conflicting values } \\
\text { among LTC employees and other } \\
\text { residents related to LG older adults. } \\
\text { Intervention Evaluation: Not }\end{array}$ \\
\hline
\end{tabular}




\begin{tabular}{|c|c|c|c|c|c|}
\hline & & & & & gathered. \\
\hline $\begin{array}{l}\text { Donald } \\
\text { son et } \\
\text { al. } \\
(2018) \\
\text { USA } \\
\text { QS: } 10\end{array}$ & $\begin{array}{l}\text { Develop an online } \\
\text { training tool designed } \\
\text { to address the } \\
\text { competencies that } \\
\text { Veteran affairs staff } \\
\text { must possess in order } \\
\text { to serve older LGBT } \\
\text { Veterans. Determine } \\
\text { the impact of the } \\
\text { training on staff } \\
\text { members' knowledge, } \\
\text { skills, and attitudes. }\end{array}$ & $\begin{array}{l}\text { Intervention: Online module. } \\
\text { Content: Factors that affect the } \\
\text { lives of older LGBT Veterans, } \\
\text { terminology, and a case vignette } \\
\text { featuring a } 71 \text { year-old Latina } \\
\text { transgender woman who was a } \\
\text { U.S. Army Veteran. Emphasis was } \\
\text { placed on intersecting identities, } \\
\text { and challenges brought on by aging } \\
\text { among LGBT. Actions participants } \\
\text { could take to develop and } \\
\text { demonstrate their competency } \\
\text { with LGBT Veterans at personal, } \\
\text { professional, institutional, and } \\
\text { systemic levels. } \\
\text { Teaching methods: Reading } \\
\text { training content. } \\
\text { Delivery: Online through Veterans } \\
\text { Affairs Talent Management } \\
\text { System. } \\
\text { Duration: Approximately } 1 \text { hour. }\end{array}$ & $\begin{array}{l}\text { Design: Single group pre- and post- } \\
\text { survey. } \\
\text { Data collection methods: Modified } \\
\text { version of Lesbian, Gay, and Bisexual } \\
\text { Knowledge and Attitudes Scale } \\
\text { (Worthington et al 2005) and Attitudes } \\
\text { Toward Transgender Individuals Scale } \\
\text { (Walch et al (2012) items from a study } \\
\text { that assessed psychologists' ability to } \\
\text { work with LGBT Veterans (Johnson \& } \\
\text { Federman, 2014) were used measure } \\
\text { skills. The survey also included } 4 \\
\text { true/false knowledge questions and a } \\
\text { measure of social desirability (Crowne } \\
\text { \& Marlowe, 1960) to control for a } \\
\text { positive or affirmative bias in } \\
\text { responses. } \\
\text { Data collection time point: Before and } \\
\text { immediately after the training. }\end{array}$ & $\begin{array}{l}\text { Sample size and location: } N=26 \text { staff } \\
\text { in one hospital completed training. } \\
22 \text { completed pre test and } 20 \text { post } \\
\text { test. } \\
\text { Sample Characteristics: } \\
\text { Discipline: nursing }(n=8) \text {, medicine } \\
(n=3) \text {, social work }(n=4) \text {, } \\
\text { occupational and physical therapy ( } n \\
=4) \text {, psychology }(n=2) \text {, chaplaincy ( } n \\
=1) \text {, recreation therapy }(n=2) \text {, and } \\
\text { administration }(n=2) \text {. } \\
\text { No further demographic data were } \\
\text { collected. }\end{array}$ & $\begin{array}{l}\text { Impact of intervention on } \\
\text { participants: Statistically significant } \\
\text { increases in knowledge (large effect } \\
\text { sizes), but not in skills, attitudes, or } \\
\text { belief assertions. Social desirability } \\
\text { did not correlate with same-time } \\
\text { measures at pre- and post- } \\
\text { assessment. } \\
\text { Intervention Evaluation: Not } \\
\text { gathered. }\end{array}$ \\
\hline $\begin{array}{l}\text { Henriq } \\
\text { uez et } \\
\text { al. } \\
\text { (2019) } \\
\text { Canada } \\
\text { QS: } 10\end{array}$ & $\begin{array}{l}\text { To articulate the } \\
\text { teaching approach } \\
\text { and methodology of an } \\
\text { unfolding LGBTQ } \\
\text { family case study for } \\
\text { undergraduate } \\
\text { nursing students and } \\
\text { to evaluate the impact } \\
\text { of the intervention. }\end{array}$ & $\begin{array}{l}\text { Intervention: Face-to-face. } \\
\text { Content: Normative aging, } \\
\text { common pathophysiologic } \\
\text { conditions associated with aging, } \\
\text { and health and cultural issues } \\
\text { unique to the older adult LGBTQ. } \\
\text { Teaching methods: Family case } \\
\text { study developed the researchers in } \\
\text { conjunction with LGBTQ } \\
\text { community; assigned pre-readings, } \\
\text { didactic lecture and discussion. } \\
\text { The ASK model was used to } \\
\text { incorporate the concepts of } \\
\text { Awareness, Sensitivity, and }\end{array}$ & $\begin{array}{l}\text { Design: Single group, pre-post- survey. } \\
\text { Data collection methods: Self } \\
\text { reported 5-item 5-point Likert survey } \\
\text { to assess knowledge and attitudes, } \\
\text { plus opportunity to provide narrative } \\
\text { feedback. Survey developed by } \\
\text { researchers and } 5 \text { questions focused } \\
\text { on LGBTQ health disparities, LGBTQ } \\
\text { terminology, strategies for creating } \\
\text { welcoming environments, self- } \\
\text { perceived effectiveness in sensitively } \\
\text { communicate with LGBTQ people and } \\
\text { comfort level in providing nursing care. } \\
\text { Data collection time point: Pre-test }\end{array}$ & $\begin{array}{l}\text { Sample size and location: } \\
\mathrm{N}=47 \\
42 \text { completed pre-post test. } \\
\text { Response rate }=89.36 \% \text {. } \\
\text { Undergraduate nursing students in } \\
\text { university setting. } \\
\text { Sample Characteristics: } \\
\text { Discipline: Nursing (students). } \\
\text { Gender: } 91,5 \% \text { female. } \\
\text { Sexual orientation: Not reported. } \\
\text { Ethnicity: Predominantly Caucasian. } \\
\text { Age: Mid } 20 \text { s. } \\
\text { Education: Undergraduate nursing }\end{array}$ & $\begin{array}{l}\text { Impact of intervention on } \\
\text { participants: Statistically significant } \\
\text { increases in student learning across } \\
\text { all five questions, including comfort } \\
\text { level in providing nursing care. } \\
\text { Students noted how the class } \\
\text { content combined with the case } \\
\text { study not only increased their } \\
\text { preparation for practice but also } \\
\text { increased their empathy. Increased } \\
\text { knowledge of family diversity, and } \\
\text { critical thought regarding the } \\
\text { intersectionality of discrimination } \\
\text { and aging were reported. }\end{array}$ \\
\hline
\end{tabular}




\begin{tabular}{|c|c|c|c|c|c|}
\hline & & $\begin{array}{l}\text { Knowledge when learning about a } \\
\text { new cultural group. The knowledge } \\
\text { component teaching on gender- } \\
\text { affirming language, health } \\
\text { promotion practices, and gender- } \\
\text { affirming care practices. The } \\
\text { awareness component involved } \\
\text { student self-reflection on personal } \\
\text { values and biases. The sensitivity } \\
\text { component involved a guest } \\
\text { speaker (mother of a trans child } \\
\text { Delivery: Instructor and a guest } \\
\text { speaker. } \\
\text { Duration: } 2 \text { three-hour classes. }\end{array}$ & $\begin{array}{l}\text { prior to receiving any curricular } \\
\text { content, but after receiving assigned } \\
\text { pre-reading. Post-test was conducted } \\
\text { after the case study. }\end{array}$ & $\begin{array}{l}\text { students. } \\
\text { Work Experience: Not relevant } \\
\text { (students). } \\
\text { Income: Not relevant (students). }\end{array}$ & $\begin{array}{l}\text { Intervention Evaluation: Students } \\
\text { highlighted the detail of the case } \\
\text { study and appreciated the flow of } \\
\text { content and the unfolding method. } \\
\text { The students' comments revealed } \\
\text { the importance of classroom learning } \\
\text { to reflect the practice environment } \\
\text { and the need to address personal } \\
\text { biases when providing health care } \\
\text { services. Students provided feedback } \\
\text { on the use of a community member } \\
\text { as a guest speaker, who was seen as } \\
\text { important to the overall impact. } \\
\text { Several students commented on the } \\
\text { realism of the scenario and how it } \\
\text { challenged them to think critically. }\end{array}$ \\
\hline $\begin{array}{l}\text { Levya } \\
\text { et al. } \\
\text { (2014) } \\
\text { USA } \\
\text { QS: } 9\end{array}$ & $\begin{array}{l}\text { To review the } \\
\text { outcomes of a cultural } \\
\text { competency training } \\
\text { for aging services } \\
\text { providers regarding } \\
\text { lesbian, gay, bisexual, } \\
\text { and transgender } \\
\text { (LGBT) older adults. }\end{array}$ & $\begin{array}{l}\text { Intervention: Face-to-face. } \\
\text { Content: 1. LGBT history, culture } \\
\text { and terminology pertinent to LGBT } \\
\text { older adults; } 2 \text {. Legal issues faced } \\
\text { by this population; 3. How to assist } \\
\text { LGBT older adults in accessing } \\
\text { culturally competent, long term } \\
\text { residential care; } 4 \text {. How to make } \\
\text { service environments more LGBT } \\
\text { friendly?. } \\
\text { Teaching methods: Four } \\
\text { workshops consisting of a panel of } \\
\text { older LGBT adults shared personal } \\
\text { experiences, a vignette exercise to } \\
\text { increase empathy and awareness } \\
\text { of biases in working with older } \\
\text { LGBT population and question and } \\
\text { answer session involving panel of } \\
\text { LGBT older adults. } \\
\text { Delivery: Panel of experts and }\end{array}$ & $\begin{array}{l}\text { Design: Single group pre-post survey. } \\
\text { Data collection methods: Survey: } 25 \\
\text { item, } 5 \text {-point Likert scale to measure } \\
\text { knowledge, skills, attitudes (KSA) and } \\
\text { awareness of current } \\
\text { policies/practices. Awareness only } \\
\text { measured in pre test. Survey also } \\
\text { included two open-ended questions on } \\
\text { applying learning to practice. } \\
\text { Data collection time point: Before and } \\
\text { presumably immediately after the } \\
\text { intervention. }\end{array}$ & $\begin{array}{l}\text { Sample size: } \\
\mathrm{N}=123.115 \text { completed the pre-test } \\
\text { and } 112 \text { the post-test. } 25,2 \% \text { were } \\
\text { LGBT older adults identifying as } \\
\text { service users. } \\
\text { Sample Characteristics: } \\
\text { Discipline: social workers, } \\
\text { counselors, nurses, first responders, } \\
\text { senior services ombudsmen, skilled } \\
\text { nursing and other residential care } \\
\text { facility managers and staff members, } \\
\text { and religious leaders. } \\
\text { Gender: } 73 \% \text { women, } 25,2 \% \text { men, } \\
\text { 0,9\% transgender (though more } \\
\text { participants identified as transgender } \\
\text { during training). } \\
\text { Sexual Orientation: } 61 \% \text { Non-LGBT, } \\
14,8 \% \text { Lesbian, } 7,8 \% \text { Gay, } 2,6 \% \\
\text { Bisexual, } 13 \% \text { declined to answer. }\end{array}$ & $\begin{array}{l}\text { Impact of intervention on } \\
\text { participants: Statistically significant } \\
\text { increases in knowledge, attitudes } \\
\text { and skills. Heterosexual participants } \\
\text { reported more knowledge and a } \\
\text { more positive attitude at the } \\
\text { conclusion of the training, as a result, } \\
\text { scores of heterosexual participants } \\
\text { more closely mirrored those of } \\
\text { lesbian/gay participants. The two } \\
\text { groups continued to differ in level of } \\
\text { skill, with lesbian/gay participants } \\
\text { reporting significantly more skills at } \\
\text { the conclusion of the training. } \\
\text { Additionally, two of the skill items } \\
\text { appeared to demonstrate a shift in } \\
\text { personal awareness of the presence } \\
\text { of homophobia and } \\
\text { heteronormativity in the workplace. } \\
\text { A low level of knowledge regarding }\end{array}$ \\
\hline
\end{tabular}




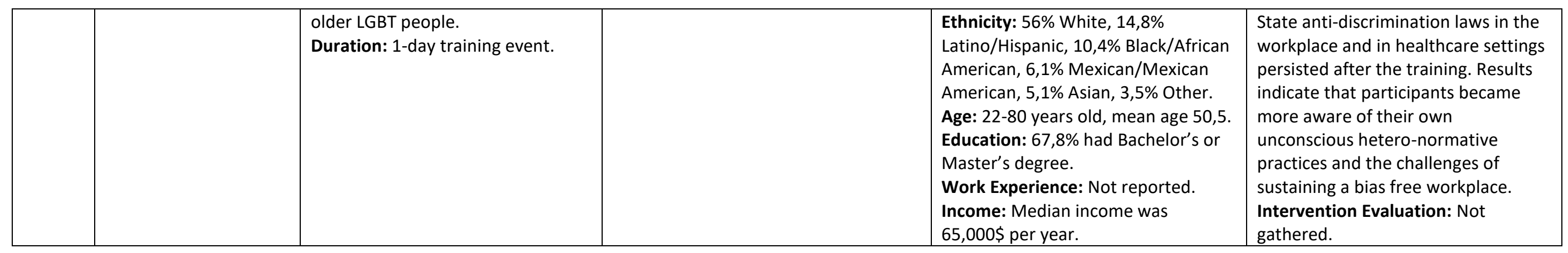




\section{Results}

\section{Nature of Interventions}

Eight studies were conducted in the USA and one was conducted in Canada (table 3). The included studies developed interventions for a variety of health and non-health related disciplines (Rogers et al., 2013; Hardacker et al., 2014; Leyva et al. 2014; Porter \& Krinsky, 2014; Hughes et al., 2016, Pelts and Galambos, 2017), including administrative workers (Gendron et al., 2013; Donaldson et al., 2018), and undergraduate student nurses (Henriquez et al., 2019).

All interventions aimed to develop cultural competency in relation to LGBT+ older adults by addressing unique issues related to the community. Hence, the content focused on exploring barriers, prejudice, assumptions and health disparities (Gendron et al., 2013; Rogers et al., 2013; Hardacker et al., 2014; Porter and Krinsky, 2014; Donaldson et al., 2018; Henriquez et al., 2019) as well as the impact of marginalization, discrimination and a lack of legal rights (Rogers et al., 2013; Hardacker et al., 2014; Leyva et al. 2014; Hughes et al., 2016, Henriquez et al., 2019). Significant emphasis within curricula was placed on addressing terminology, language and intersecting identities (Gendron et al., 2013; Donaldson et al., 2018; Henriquez et al., 2019), while interventions described by Henriquez et al. (2019); Donaldson et al., (2018) and Hardacker et al. (2014) specifically addressed transgender issues.

Diverse teaching and learning methods were used across studies, including didactic teaching in combination with interactive exercises, small group activities and facilitated discussion (Gendron et al., 2013; Hardacker et al., 2014; Porter and Krinsky, 2014; Leyva et al. 2014; Henriquez et al., 2019). The use of documentary footage and videos was common (Gendron et al., 2013; Rogers et al., 2013; Pelts and Galambos, 2017), as was engagement with personal narratives (Rogers et al., 2013; Leyva et al. 2014; Pelts and Galambos, 2017; Henriquez et al., 2019). Three studies utilised fictional case studies, based on life examples (Leyva et al. 2014; Donaldson et al., 2018; Henriquez et al., 2019) while one intervention used a theatre experience (Hughes et al., 2016)

With the exception of Donaldson et al.'s (2018) study, most interventions included individuals from the LGBT+ community or LGBT+ organizations in either the development or 
delivery of the intervention. One intervention was specifically developed by LGBT+ identified providers working in the older peoples services (Porter and Krinsky, 2014), while others used a collaborative approach bringing together LGBT+ activists and researchers, and academics (Gendron et al., 2013; Leyva et al. 2014; Hughes et al., 2016; Pelts and Galambos, 2017). One intervention which used cases studies (Henriquez et al., 2019) was based on interviews with nursing and LGBT+ community members. These were consulted a second time to validate the realism of the case study developed. Members of the LGBT+ community were also involved in the delivery of the intervention (Rogers et al., 2013; Porter and Krinsky, 2014; Leyva et al 2014) and in one study involved as auditors of the delivery (Leyva et al 2014). In one intervention, the mother of a trans child was invited to share her personal story (Henriquez et al., 2019).

All interventions were delivered in face-to-face format, except for Donaldson et al. (2018) which was conducted solely online. The duration of most interventions ranged from one to six hours. The online intervention was presumed to take one hour (Donaldson et al., 2018), whereas Leyva et al.'s (2014) intervention was a one-day event. Hardacker et al.'s (2014) intervention included six 1-hour modules delivered over six consecutive weeks or in multiple presentations per day. In two studies (Rogers et al., 2013; Pelts and Galambos, 2017) the duration wasn't reported, but based on the description, the interventions lasted a few hours.

\section{Evaluation designs and sample included in evaluation}

All of the evaluation designs were descriptive in nature using a single group pre- and posttest design, except for Rogers et al. (2013) who only used a post-test design. While the studies endeavoured to capture some change in the participants, none of the studies were underpinned by change theory. All of the studies measured the impact of the intervention on knowledge or awareness of LGBT+ issues. Some studies also included changes in attitudes towards LGBT+ older adults (Porter and Krinsky, 2014; Pelts and Galambos, 2017; Donaldson et al., 2018; Leyva et al., 2014), skills/comfort levels in the provision of care (Gendron et al., 2013; Donaldson et al.,2018; Leyva et al., 2014; Henriquez et al., 2019; Porter and Krinsky, 2014) and participants' intention to use the knowledge in practice (Hughes, et al.,2016; Porter and Krinsky, 2014). In addition, participants' satisfaction with or 
feedback on the intervention itself was gathered in some studies (Gendron et al., 2013; Rogers et al., 2013; Hughes et al., 2016; Hardacker et al., 2014; Henriquez et al., 2019).

While all studies used surveys, only two reported using surveys previously used by other researchers. Pelts and Galambos (2017) used the Components of Attitudes Towards Homosexuality Scale (CATH; LaMar and Kite, 1998), while Donaldson et al. (2018) adjusted the Lesbian, Gay, and Bisexual Knowledge and Attitudes Scale for Heterosexuals (LGB-KASH; Worthington et al., 2005) and the Attitudes Toward Transgender Individuals Scale (ATTIS; Walch et al., 2012). One study adapted questions used in another study to assess psychologists' ability to work with LGBT+ veterans (Johnson \& Federman, 2014). The remaining studies appeared to design their own survey using Likert scale and binary category (e.g.s true/false and yes/no) questions. To elicit feedback on the impact and the quality of the interventions, open-ended questions were added to some surveys. None of the studies reported on the validity or reliability of the research tools used.

In some studies, the survey element was complimented with data from observations, field notes, interviews, focus groups and/or group discussions (Gendron et al., 2013; Rogers et al., 2013; Pelts and Galambos, 2017; Henriquez et al., 2019). In all cases of pre- and post-test designs the data were collected before and immediately after the intervention and in the case of Hardacker et al. (2014) before and after each module. Rogers et al. (2013) only collected data post intervention, while the qualitative and observational data in Gendron et al. (2013) was collected before, during and after the intervention.

The sample sizes varied from small $(n=26)$ to large $(n=848)$, and predominately consisted of women (75\%-91,5\%), self-identifying as Caucasian/White (36\%-92\%) or African American/Black (max. 48\%) and heterosexual (61-82\%). Four studies reported on the specific disciplines of those attending the interventions. The most common attendees were nurses, while smaller numbers of social workers, physical therapists and medical practitioners were also in attendance. (Table 3 provides more detailed information).

\section{Impact of interventions}

Given the lack of consistency in the tools used to evaluate the impact it was not possible to aggregate outcomes, however the findings of all studies suggest an increase in knowledge (awareness) of LGBT+ specific issues, needs and resources and comfort levels. One study 
reported a lower increase in knowledge in nursing homes and home health care settings, compared to hospitals and educational settings (Hardacker et al., 2014), while such differences were not reported in Rogers et al.'s (2013) study. In Gendron et al.'s (2013) study an increase in awareness was not demonstrated in every site, while the comfort levels around providing care to transgender persons decreased after Porter and Krinsky's (2014) intervention. Furthermore, interventions helped participants reflect on their biases, attitudes and values (Rogers et al., 2013) and increased positive attitudes towards older LGBT+ adults (Hardacker et al., 2014; Porter and Krinsky, 2014; Leyva et al. 2014), though this was more moderate in one study (Pelts and Galambos, 2017). There was some evidence of increased empathy for LGBT+ older adults (Rogers et al., 2013; Hardacker et al., 2014; Henriquez et al., 2019), as well as behaviour intentions to use knowledge or skills gained within practice (Porter and Krinsky, 2014; Hughes et al., 2016; Henriquez et al., 2019). However, in terms of application to practice, prejudice of staff, residents or their families was reported as a challenge to improving care, as were rigid organizational systems and a lack of training for all staff (Pelts and Galambos, 2017; Hughes et al., 2016).

\section{Views on the intervention}

Some studies gathered additional data on participants' views on the intervention, including delivery. High ratings for overall satisfaction were reported (Gendron et al., 2013; Rogers et al., 2013; Hardacker et al., 2014), with participants recommending the intervention to their colleagues or considering that the training should be mandatory (Gendron et al., 2013) in college courses and agency settings (Rogers et al., 2013). Furthermore, panel presentations by diverse LGBT+ presenters received high ratings, as did interactive exercises (Gendron et al., 2013; Hughes et al., 2016; Henriquez et al., 2019). Participants also valued the ability of the facilitators to create a safe space (Rogers et al., 2013). Some participants reported a need for further information regarding specific health and policy issues (Rogers et al., 2013) and expressed a desire to better understand the context and personal experiences of LGBT+ older adults (Pelts and Galambos, 2017).

Not all studies, however, reported such positive feedback, with some reporting a reluctance by some participants to engage. Hardacker et al. (2014:261) described how younger participants demonstrated more knowledge and eagerness to attend training, while others 
demonstrated signs of cultural blindness (e.g. reporting, "we treat everyone the same") which may explain their reluctance to engage. Hughes et al (2016:302) reported similar comments by participants about their facility being a "non-biased facility" or that "we treat all patients with respect and treat everyone the same" and question the need to discuss gender and sexual orientation ("I don't see why we need to keep talking about how we are different, rather than how we are alike.")

These comments suggest that perhaps some participants see discussion of LGBT+ issues as LGBT+ older adults asking for special treatment, as opposed to challenging heteronormative assumptions. In studies with participants from more diverse religious backgrounds, the discussions were reported as more challenging, with two studies reporting on conflict of values, especially related to religion (Hardacker et al., 2014; Pelts and Galambos, 2017).

\section{Discussion}

The aim of this review was to describe interventions used to educate the health and social care workforce on the experiences and needs of older LGBT+ adults. Although, due to the heterogeneity of interventions, direct comparison between studies was not possible, the findings do suggest that educational interventions, irrespective of duration, have positive impacts on knowledge, awareness, and attitudes, however long term sustainability and impact on practice were not measured. The findings also indicate that education on LGBT+ issues can be approached from an interdisciplinary perspective. While the interventions mostly focused on LGBT+ issues in general, few addressed transgender older adults. One of the studies that specifically included transgender issues, reported that while knowledge scores increased from pre to post test, comfort scores in relation to providing care to a transgender person decreased (Porter and Krinsky, 2014). While this may be interpreted as a negative outcome, an alternative reading could be that while the programme enhanced knowledge it also increased participants' awareness of diversity and the specific health and social care needs of older transgender adults, thus giving rise to greater discomfort in terms of care provision. Developing comfort and confidence is something that occurs with time and with practice, especially if practitioners are exposed to good role models with in the practice setting (Fronek et al. 2011; Bauer et al. 2019). Higgins et al. (2012:2566) suggests that 'mentoring and clinical supervision within the practice environment, with opportunities 
to observe others and to receive formal and informal feedback on one's own performance, may also provide additional ways to enhance comfort levels'.

Intervention and evaluation designs rarely measure participants' skills in addressing homophobic or transphobic behaviour in care settings. Porter and Krinsky (2014) and Leyva et al. (2014) did measure some change in awareness of its presence and intentions of responding to such remarks or behaviour. However, in Porter and Krinsky's (2014) study this was in the context of assessing capacity to create a welcoming environment for older LGBT+ adults rather than to counter homophobia or transphobia. Otherwise, as participants in Pelts and Galambos (2017) have noticed, there is a lack of knowledge and skills in responding to and providing care to older adults who are homophobic. The authors recommend research on relationships between residents of different sexual orientations and its effects on quality of care and life in health and social care settings.

While some studies did explore intention to use knowledge gains in practice and included reflection on ways of applying learning to practice (Hughes et al., 2016; Pelts and Galambos, 2017), knowledge acquisition, enhanced awareness or positive intention to use learning does not necessarily mean transfer into practice. The ultimate test of any intervention is whether the changes accrued impacts positively on participants' day-to-day interactions with LGBT+ older adults. As no study explored actual change in practice from the perspective of the participants or LGBT+ older adults, the authors' ability to comment on the overall impact of interventions on outcomes for users of services is limited. In addition, in terms of timeframe the findings only refer to outcomes on immediate completion of the programme. In the absence of longitudinal follow-up data, it is not possible to say if this increase was sustainable over time. This is important given that other education interventions in the area of sexuality have reported a trend of decline at follow-up (Higgins et al. 2019a, Byrne et al. 2006; Post et al. 2008).

Teaching methods used in the interventions mainly comprised didactic approaches, although interactive activities, especially storytelling were shown to be important, effective, and in some cases, central methods in addressing LGBT+ older adults' experiences and needs. Where LGBT+ older adults were involved (in person or video) in telling their personal stories, participants reported enhanced engagement with the intervention, awareness of 
LGBT+ issues and increased empathy (Gendron et al., 2013; Rogers et al., 2013; Hughes et al., 2016; Pelts and Galambos, 2017; Leyva et al., 2014). The inclusion of older LGBT+ adults in the intervention design and delivery, is a strategy that is now recognised as a core principle underpinning the provision of education to health and social care practitioners on LGBT+ older adults (Higgins et al., 2019b; Higgins et al., 2019c; Cannon et al. 2017). While the relationship between the degree of citizen involvement and the outcomes has yet to be researched, the inclusion of LGBT+ older adults is of significance, given the importance placed on patient and public involvement and co-production within health and social care policy and practice (Ocloo and Matthews, 2016; Sapouna, 2020).

\section{Limitations}

The positive results reported from this review need to be considered in the context of findings on the quality of the studies, including sample size, a lack of quality tools tested for reliability and validity, an absence of randomised controlled evaluation designs that were underpinned by theory and incorporated a longitudinal element. Many studies did not describe the method of recruitment or provide information on refusal or attrition rates, therefore selection bias was possible. In addition, all of the studies were undertaken in North America, which raises questions regarding transferability to other countries, where historical, legal, cultural and political context may differ. As most of the outcomes were measured by self-reporting and with none addressing behaviour changes in practice, there is a need, for additional research to determine if the positive impacts noted are sustained long term, as suggested by some study authors (Rogers et al., 2013; Leyva et al. 2014; Hardacker et al., 2014; Porter and Krinsky, 2014; Pelts and Galambos, 2017). Some also recommended more robust randomized control group designs (Hughes et al., 2016; Henriquez et al., 2019) and standardized measures to assess impact on cultural competency (Leyva et al. 2014; Donaldson et al, 2018). Porter and Krinsky (2014) also recommended incorporating organisational level surveys into the design in order to appraise cultural, policies and practice changes, with others pointing out the need for further research into barriers to cultural change.

\section{Conclusion}


While there were clear methodological limitations to many of the studies included in this review, the studies do indicate the benefit of education programmes that are facilitated in a sensitive and inclusive manner, with LGBT+ older adults. While some disciplines were not as well represented as nursing, in those availing of the education intervention, the studies do highlight the feasibility of providing education to multidisciplinary groups. However, future studies would benefit by having a larger proportion of staff taking part from all disciplines to allow for comparisons across disciplines. In addition, research is required to explore the long-term impact of education on change within practice, including change in organisational culture.

\section{Implications for nurse management}

LGBT+ affirmative policies and practices are open, inclusive, non-discriminatory and welcoming of those that identify as LGBT+. Nurse managers have a critical role to play in supporting the development of a culturally competent and inclusive workforce, through the provision of education on LGBT+ issues.

\section{References}

Bauer, M., Haesler, E., \& Fetherstonhaugh, D. (2019). Organisational enablers and barriers to the recognition of sexuality in aged care: A systematic review. Journal of Nursing Management, 27(4), 858-868. https://doi.org/10.1111/jonm.12743

Bell, S.A., Bern-Klug, M., Kramer, K.W.O., \& Saunders, J.B. (2010). Most Nursing Home Social Service Directors Lack Training in Working With Lesbian, Gay, and Bisexual Residents. Social Work in Health Care, 49(9), 814-831. https://doi.org/10.1080/00981389.2010.494561

Bloemen, E.M., Rosen, T., LoFaso, V.M., Lasky, A., Church, S., Hall, P., Weber, T., \& Clark, S. (2019). Lesbian, Gay, Bisexual, and Transgender Older Adults' Experiences With Elder Abuse and Neglect. Journal of American Geriatrics Society, 67(11), 2338-2345. https://doi.org/10.1111/jgs.16101

Brennan N., \& Mattick, K. (2012). A systematic review of educational interventions to change behaviour of prescribers in hospital settings, with a particular emphasis on new prescribers. British Journal of Clinical Pharmacology, 75(2), 359-372. https://doi.org/10.1111/i.1365$\underline{2125.2012 .04397 . x}$

Burton, C.W., Lee, J.A., Waalen, A., \& Gibbs, L.M. (2019). "Things Are Different Now But": Older LGBT Adults' Experiences and Unmet Needs in Health Care. Journal of Transcultural Nursing. https://doi.org/10.1177/1043659619895099 
Byrne, A., Watson, R., Butler, C., \& Accoroni, A. (2006). Increasing the confidence of nursing staff to address the sexual health needs of people living with HIV: the use of motivational interviewing. AIDS Care, 18(5), 501-504. https://doi.org/10.1080/09540120500358985

Cannon, S.M., Shukla, V., \& Vanderbilt, A.A. (2017). Addressing the healthcare needs of older Lesbian, Gay, Bisexual, and Transgender patients in medical school curricula: a call to action. Medical Education Online, 22(1). https://doi.org/10.1080/10872981.2017.1320933

Cottrell, D.B. (2020). Considering the Needs of Older Sexual and Gender Minority People. The Journal for Nurse Practitioners, 16(2), 146-150. https://doi.org/10.1016/i.nurpra.2019.11.013

De Guzman, F.L.M., Ngalee Moukoulou, L.N., Scott, L.D., \& Zerwic, J.J. (2018). LGBT inclusivity in health assessment textbooks. Journal of Professional Nursing, 34(6), 483-487.

https://doi.org/10.1016/i.profnurs.2018.03.001

Donaldson, W., Smith, H.M., \& Parrish, B.P. (2018). Serving All Who Served: Pilloting an Online Tool to Support Cultural Competency with LGBT U.S. Military Veterans in Long-Term Care. Clinical Gerontologist, 42(2), 185-191. https://doi.org/10.1080/07317115.2018.1530323

Emlet, C.A. (2016). Social, Economic, and Health Disparities Among LGBT Older Adults. Journal of the American Society on Aging, 40(2), 16-22. https://www.jstor.org/stable/26556193

Fredriksen-Goldsen, K.I., Kim, H.J., Barkan, S.E., Muraco, A., \& Hoy-Ellis, C.P. (2013). Health Disparities Among Lesbian, Gay, and Bisexual Older Adults: Results From a Population-Based Study. American Journal of Public Health, 103(10), 1802-1809. https://doi.org/10.2105/AJPH.2012.301110

Fredriksen-Goldsen, K.I., Bryan, A.E.B., Jen, S., Goldsen, J., Kim, H.J., \& Muraco, A. (2017). The Unfolding of LGBT Lives: Key Events Associated With Health and Well-being in Later Life. Gerontologist, 57(1), 15-29. https://doi.org/10.1093/geront/gnw185

Fronek P., Kendall M., Booth S., Eugarde E., \& Geraghty T. (2011). A longitudinal study of sexuality training for the interdisciplinary rehabilitation team. Sexuality and Disability, 29(2), 87-100. https://doi.org/10.1007/s11195-010-9177-1

Gendron, T., Maddux, S., Krinsky, L., White, J., Lockeman, K., Metcalfe, Y., \& Aggarval, S. (2013). Cultural Competence Training for Healthcare Professionals Working with LGBT Older Adults. Educational Gerontology, 39(6), 454-463. https://doi.org/10.1080/03601277.2012.701114

Greene, M.Z., France, K., Kreiders, E.F., Wolfe-Roubatis, E., Chen, K.D., Wu, A., \& Yehia, B.R. (2018). Comparing medical, dental, and nursing students' preparedness to address lesbian, gay, bisexual, transgender, and queer health. https://doi.org/10.1371/journal.pone.0204104.

Grossman, A.H., Frank, J.A., Graziano, M.J., Narozniak, D.R., Mendelson, G., Hassan El, D., \& Patouhas, E.S. (2014). Domestic Harm and Neglect Among Lesbian, Gay, and Bisexual Older Adults. Journal of Homosexuality, 61(12), 1649-1666. https://doi.org/10.1080/00918369.2014.951216

Hardacker, C.T., Rubinstein, B., Hotton, A., \& Houlberg, M. (2014). Adding silver to the rainbow: the development of the nurses' health education about LGBT elders (HEALE) cultural competency curriculum. Journal of Nursing Management, 22(2), 257-266. https://doi.org/10.1111/jonm.12125 
Henriquez, N., Hyndman, K., \& Chachula, K. (2019). It's Complicated: Improving Undergraduate Nursing Students' Understanding Family and Care of LGBTQ Older Adults. Journal of Family Nursing, 25(4), 506-532. https://doi.org/10.1177/1074840719864099

Higgins A., Sharek D., Nolan M., Sheerin, B., Flanagan, P., Slaicuinaite, S., Donnel, M.S., \& Walsh, H. (2012). Mixed methods evaluation of an interdisciplinary sexuality education programme for staff working with people who have an acquired physical disability. Journal of Advanced Nursing, 68(11), 2559-2569. https://doi.org/10.1111/j.1365-2648.2012.05959.x

Higgins, A., Downes, C., Daly, L., Begley, T., Sharek, D., \& de Vries, J. (2019a). Capacity building in sexual health promotion: a longitudinal evaluation of a training-the-trainer programme in Ireland. Sexual and Relationship Therapy. https://doi.org/10.1080/14681994.2019.1566604

Higgins, A., Downes, C., Sheaf, G., Bus, E., Connell, S., Hafford-Letchfield, T., Jurček, A., Pezzella, A., Rabelink, I., Robotham, G., Urek, M., van der Vaart, N., \& Keogh, B. (2019b). Pedagogical principles and methods underpinning education of health and social care practitioners on experiences and needs of older LGBT+ people: Findings from a systematic review. Nurse Education in Practice, 40(7). https://doi.org/10.1016/j.nepr.2019.102625

Higgins, A., Keogh, B., Bus, E., Connell, S., Hafford-Letchfield, T., Jurček, A., Pezzella, A., Rabelink, I., Robotham, G., Urek, M., \& Van der Vaart, N. (2019c). Best practice principles on developing LGBT cultural competence in health and social care education. Being Me Project team. https://beingme.eu/public/application/downloads/resources/being-me-best-practice-principles20200622.pdf

Hughes, A.K., Luz, C., Hall, D., Gardner, P., Hennessey, C.W., \& Lammers, L. (2016). Transformative Theatre: A Promising Educational Tool for Improving Health Encounters With LGBT Older Adults. Gerontology and Geriatrics Education, 37(3), 292-306. https://doi.org/10.1080/02701960.2015.1127812

Johnson, L., \& Federman, E. J. (2014). Training, experience, and attitudes of VA psychologists regarding LGBT issues: Relation to practice and competence. Psychology of Sexual Orientation and Gender Diversity, 1(1), 10-18. https://doi.org/10.1037/sgd0000019

Knauer, N.J. (2016). LGBT Older Adults, Chosen Family and Caregiving. Journal of Law and Religion, 31(2), 150-168. https://doi.org/10.1017/ilr.2016.23

Kothari D., Gourevitch, M.N., Lee J.D., Grossman E., Truncali A., Ark T.K., \& Kalet A.L. (2011). Undergraduate medical education in substance abuse: a review of the quality of the literature. Academic Medicine, 86(1), 98-112. https://doi.org/10.1097/ACM.0b013e3181ff92cf

LaMar, L., \& Kite, M. (1998). Sex differences in attitudes toward gay men and lesbians: A multidimensional perspective. Journal of Sex Research, 35(2), 189-196.

https://doi.org/10.1080/00224499809551932

Leyva, V.L., Breshears, E.M., \& Ringstad, R. (2014). Assessing the Efficacy of LGBT Cultural Competency Training for Aging Services Providers in California's Central Valley. Journal of Gerontological Social Work, 57(2-4), 335-348. https://doi.org/10.1080/01634372.2013.872215

LLayton, C.K., \& Caldas, L.M. (2020). Strategies for inclusion of lesbian, gay, bisexual, transgender, queer, intersex, and asexual (LGBTQIA+) education throughout pharmacy school curricula. Pharmacy Practice, 18(1), 1862. https://doi.org/10.18549/PharmPract.2020.1.1862 
McCabe, S.E., Hughes, T.L., Bostwick, W.B., West, B.T., \& Boyd, C.J. (2009). Sexual orientation, substance use behaviors and substance dependence in the United States. Addiction, 104, 1333-1345. https://doi.org/10.1111/i.1360-0443.2009.02596.x

Nowaskie, D.Z., \& Sowinski, J.S. (2019). Primary Care Providers' Attitudes, Practices And Knowledge in Treating LGBTQ Communities. Journal of homosexuality, 66(13), 1927-1947. https://doi.org/10.1080/00918369.2018.1519304

Ocloo, J., \& Matthews, R. (2016). From tokenism to empowerment: progressing patient and public involvement in healthcare improvement. BMJ Quality and Safety, 25(8), 626-632.

http://dx.doi.org/10.1136/bmiqs-2015-004839

Pelts, M.D., \& Galambos, C. (2017). Intergroup Contact: Using Storytelling to Increase Awareness of Lesbian and Gay Older Adults in Long-Term Care Settings. Journal of Gerontological Social Work, 60(6-7), 587-604. https://doi.org/10.1080/01634372.2017.1328478

Porter, K.E., \& Krinsky, L. (2014). Do LGBT Aging Trainings Effectuate Positive Change in Mainstream Elder Service Providers?. Journal of Homosexuality, 61(1), 197-216. https://doi.org/10.1080/00918369.2013.835618

Post, M.W.M., Gianotten, W.L., Heihnen, L., Hille Ris Lambers, E.J., Willems, M. (2008). Sexological competence of different rehabilitation disciplines and effects of a discipline-specific sexological training. Sexuality and Disability, 26(1), 3-14. https://doi.org/10.1007/s11195-007-9068-2

Putney, J.M., Keary, S., Heber, N., Krinsky, L., \& Halmo, R. (2018). "Fear Runs Deep:" The Anticipated Needs of LGBT Older Adults in Long-Term Care. Journal of Gerontological Social Work, 61(8), 887907. https://doi.org/10.1080/01634372.2018.1508109

Reed, D. A., Cook, D. A., Beckman, T. J., Levine, R. B., Kern, D. E., \& Wright, S. M. (2007). Association between funding and quality of published medical education research. JAMA, 298(9), 1002-1009. https://doi.org/10.1001/jama.298.9.1002

Rogers, A., Rebbe, R., Gardella, C., Worlein, M., \& Chamberlain, M. (2013). Older LGBT Adult Training Panels: An Opportunity to Educate About Issues Faced by the Older LGBT Community. Journal of Gerontological Social Work, 56(7), 580-595. https://doi.org/10.1080/01634372.2013.811710

Sapouna, L. (2020). Service-user narratives in social work education; Co-production or co-option?. The International Journal of Social Work Education.

https://doi.org/10.1080/02615479.2020.1730316

Smith, R., \& Learman L.A. (2017). Plea for MERSQI: The Medical Education Research Study Quality Instrument. Obstetrics Gynecology, 130(4), 686-690.

https://doi.org/10.1097/AOG.0000000000002091

Smith, R.W., Altman, J.K., Meeks, S., \& Hinrichs, K.L.M. (2019). Mental Health Care for LGBT Older Adults in Long-Term Care Settings: Competency, Training, and Barriers for Mental Health Providers. Clinical Gerontologist, 42(2), 198-203. https://doi.org/10.1080/07317115.2018.1485197

Stonewall. (2011). Lesbian, Gay \& Bisexual People in Later Life. United Kingdom: Stonewall. https://www.stonewall.org.uk/system/files/LGB_people_in_Later_Life_2011_.pdf 
United Nations, Department of Economic and Social Affairs. (2019). World Population Ageing 2019: Highlights. United Nations. https://www.un.org/en/development/desa/population/publications /pdf/ageing/WorldPopulationAgeing2019-Highlights.pdf

United Nations Population Fund and Help Age International. (2012). Ageing in the Twenty- First Century: A Celebration and a Challenge. United Nations Population Fund and HelpAge International. https://www.unfpa.org/sites/default/files/pub-pdf/Ageing\%20report.pdf

Yarns, B.C., Abrams, J.M., Weeks, T.W., \& Sewell, D.D. (2016). The Mental Health of Older LGBT Adults. Current Psychiatry Reports, 18(60). https://doi.org/10.1007/s11920-016-0697-y

Zelle, A., \& Arms, T. (2015). Psychosocial Effects of Health Disparities of Lesbian, Gay, Bisexual, and Transgender Older Adults. Journal of Psychosocial Nursing and Mental Health Services, 53(7), 25-30. https://doi.org/10.3928/02793695-20150623-04

Walch, S. E., Ngamake, S. T., Francisco, J., Stitt, R. L., \& Shingler, K. A. (2012). The attitudes toward transgendered individuals scale: Psychometric properties. Archives of Sexual Behavior, 41(5), 12831291. https://doi.org/10.1007/s10508-012-9995-6

Wilson, K., Kortes-Miller, K., Stinchcombe, \& A., (2018). Staying Out of the Closet: LGBT Older Adults' Hopes and Fears in Considering End-of-Life. Canadian Journal on Aging, 37(1), 22-31.

https://doi.org/10.1017/s0714980817000514

Worthington, R. L., Dillon, F. R., \& Becker-Schutte, A. M. (2005). Development, reliability, and validity of the lesbian, gay, and bisexual knowledge and attitudes scale for heterosexuals (LGB-KASH). Journal of Counseling Psychology, 52(1), 104-118. https://doi.org/10.1037/0022-0167.52.1.104 